\title{
HYPOXIA AMONG PATIENTS ON THE LIVER-TRANSPLANT WAITING LIST
}

\author{
Hipóxia entre os pacientes na lista de espera para transplante de fígado \\ Lucas Souto NACIF, Wellington ANDRAUS, Kathryn SARTORI, Carlos Marlon BENITES, \\ Vinicius Rocha SANTOS, Joel Avancini ROCHA-FILHO, Luiz Carneiro D'ALBUQUERQUE
}

From the Divisão de Transplantes de Fígado e Órgãos do Aparelho Digestivo, Hospital das Clínicas, Departamento de Gastroenterologia, Faculdade de Medicina, Universidade de São Paulo, São Paulo, SP (Liver and Gastrointestinal Transplant Division, Department of Gastroenterology, University of São Paulo, School of Medicine, São Paulo, SP), Brazil

HEADINGS - Liver transplantation. Hypoxemia. Liver-transplant waiting list. Hepatopulmonary syndrome.
ABSTRACT - Background: Hepatopulmonary syndrome is formed by a triad of liver disease, intrapulmonary vascular dilatation and changes in blood gases. This condition is present in $4-32 \%$ of patients with cirrhosis. Aim: To analyze the blood gas changes data of patients in liver-transplant waiting list. Method: Clinical data of 279 patients in liver transplantation waiting list in May 2013 were studied. Overall patient was analyzed by the demographic aspects, laboratorial and image findings on exams that determine lung disease (hypoxemia) in these cirrhotic patients. The mean values and standard deviations were used to examine normally distributed variables. Results: There was a high prevalence of male patients $(68 \%)$; the mean age was $51( \pm 5,89)$ years, and the predominant reason for listing was hepatitis $C$ cirrhosis. The MELD score mean was $16 \pm 5,89$, without prioritization or special situation. The most common blood type was $O$ in 129 cases (46\%) and the mean of body max index was $25,94 \pm 4,58$. Regarding arterial blood gas tests was observed 214 patients with $\mathrm{PaO} 2<90 \mathrm{mmHg}, 80$ with $\mathrm{PaO} 2<80 \mathrm{mmHg}$ and 39 with $\mathrm{PaO} 2<50 \mathrm{mmHg}$. In relation to $\mathrm{O}_{2}$ saturation, 50 patients had $<90 \%, 33<80 \%$ and $10<50 \%$. Conclusion: Was observed a high rate of hypoxemia in patients on waiting list liver transplant. Due to the high severity and morbidity, is suggested better monitoring and therapeutic support to hypoxemic patients on liver transplant waiting list.

\section{Correspondence: \\ Lucas Souto Nacif \\ E-mail: lucasnacif@usp.br}

Financial source: none

Conflicts of interest: none

Received for publication: 13/09/2013

Accepted for publication: 17/12/2013

DESCRITORES - Transplante de fígado. Hipoxemia. Lista de espera para transplante de fígado. Síndrome hepatopulmonar.
RESUMO - Racional: A síndrome hepatopulmonar é formada por tríade clínica com doença do fígado, dilatação vascular intrapulmonar e alterações nos gases sanguíneos. Esta condição está presente em 4-32\% dos pacientes com cirrose. Objetivo: Analisar as alterações gasométricas nos pacientes em lista de espera de transplante de fígado. Método: Foram estudados dados clínicos de 279 pacientes na lista de espera para transplante hepático em maio de 2013. Foram analisados aspectos demográficos, gasometria arterial e achados de imagem que determinam a doença pulmonar (hipoxemia) nestes pacientes cirróticos. Os valores médios e desvios-padrão foram utilizados para examinar as variáveis normalmente distribuídas. Resultados: Houve alta prevalência de homens $(68 \%)$; a idade média foi de $51( \pm 5,89)$ anos; e a razão predominante para listar para o transplante foi cirrose pelo vírus C. O MELD médio foi de $16 \pm 5,89$, sem priorização ou situação especial. O tipo de sangue mais comum foi 0,129 casos (46\%) e a média do índice de massa corporal foi $25,94 \pm 4,58$. Com relação aos exames de gasometria arterial, observou-se 214 pacientes com $\mathrm{PaO} 2<90 \mathrm{mmHg}, 80$ com PaO2 <80 mmHg e 39 com $\mathrm{PaO} 2<50 \mathrm{mmHg}$, e em relação à saturação de $\mathrm{O}_{2,} 50$ pacientes < $90 \%$, 33 pacientes $<80 \%$ e 10 pacientes $<50 \%$. Conclusão: Observou-se alta taxa de hipoxemia nos pacientes em lista de transplante de fígado; devido à elevada gravidade e morbidade, sugere-se melhor seguimento e suporte terapêutico aos doentes hipoxêmicos na lista de espera para o transplante de fígado. 
INTRODUCTION

$\mathrm{H}$ epatopulmonary syndrome (HPS) is defined as clinical triad of liver disease, intrapulmonary vascular dilatation and hypoxemia. It is present in $4-32 \%$ of patients with cirrhosis. Its pathogenesis is not well defined, but it is speculated that a combination of factors, such as an imbalance in the response of vascular endothelin receptors, pulmonary microvascular remodeling and genetic predisposition, leads to intrapulmonary vascular dilatation and bacterial translocation ${ }^{1-4}$

Initially the hypoxemia in these patients responds to low-flow supplemental oxygen, but, over time, the need for oxygen supplementation. Currently, no pharmacological intervention can readily improve arterial oxygenation and alter the course of HPS. Thus, liver transplantation is the only effective therapeutic option for its resolution 4,5 .

The aim of this study was to analyze the blood gas changes data of patients in liver-transplant waiting list.

\section{METHODS}

The study was approved by the Institutional Review Board fulfilling all requirements to retrospective studies in humans.

Clinical data of 279 patients in liver-transplant waiting list in May 2013 were studied. They were analyzed by demographic and laboratorial aspects, and the image findings that determine lung disease (hypoxemia) in these cirrhotic patients.

The statistical analysis was performed using GraphPad Prism Software ${ }^{\circledR}$. Differences were considered significant at $p<0.05$. Data were presented as the mean \pm standard deviation (SD) for continuous variables.

\section{RESULTS}

There was a high prevalence of men (68\%); the mean age was $51( \pm 5,89)$ years and the predominant reason for listing was hepatitis C cirrhosis. The MELD mean score was $16 \pm 5,89$, without prioritization or special situation. The most common blood type was $\mathrm{O}$ in 129 cases (46\%) and the mean of body max index was $25,94 \pm 4,58$.

\section{Arterial blood gas analysis}

Regarding arterial blood gas tests were observed 214 patients with $\mathrm{PaO}_{2}<90 \mathrm{mmHg}$, 80 with $<80 \mathrm{mmHg}$ and 39 with $<50 \mathrm{mmHg}$. The oxigen saturations $\left(\mathrm{O}_{2}\right.$ saturation) were in 50 patients $<90 \%$, in $33<80 \%$ and in $10<50 \%$ (Figure 1).

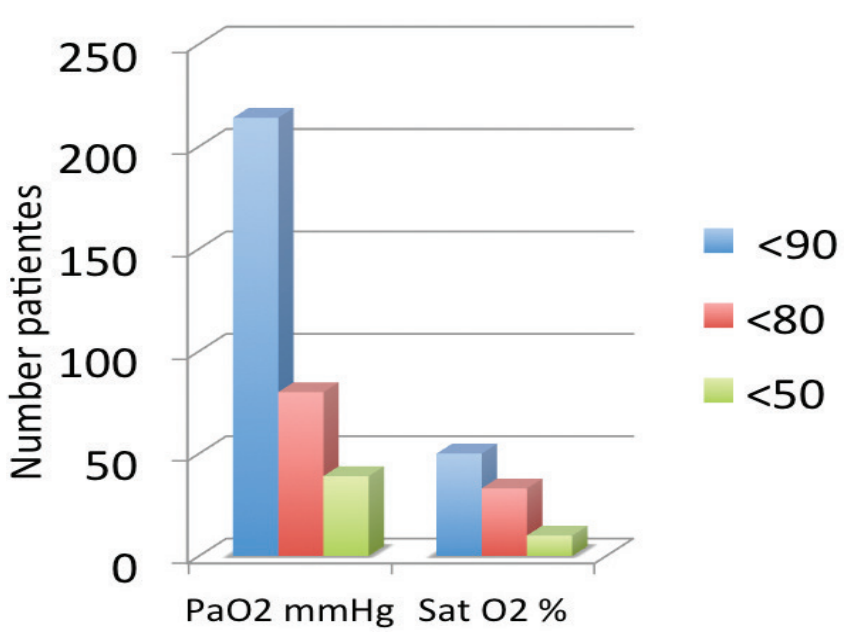

FIGURE 1 - Arterial blood gas analysis in overall patients $(n=214)$ on liver-transplant waiting list

\section{DISCUSSION}

Were observed high values of desaturation in this population. Moreover, differential diagnosis must to be done to excluded pulmonary and clinical findings that simulate disease of the lung in end-stage of liver disease.

HPS can normally be diagnosed with noninvasive tests. An elevated alveolar-arterial gradient and decrease in arterial blood gas occurs due to the dilatation of pulmonary vasculature leading to shunt with ventilation-perfusion mismatch ${ }^{4-8}$.

The majority of patients are either asymptomatic, particularly if diagnosed during evaluation for liver transplantation. Some cases develop the insidious onset of dyspnea ${ }^{7,9}$. In addition, respiratory symptoms are common in end-stage of liver disease owing to poor physical condition, smoking, ascites or other lung disease ${ }^{4,9}$. Chest radiography, chest CT and pulmonary function tests are often performed to evaluate dyspnea in cirrhosis and during evaluations for liver transplantation ${ }^{10}$. Commonly, chest radiographic findings are normal in HPS, even when hypoxemia is severe.

No effective medical therapy for HPS is available although a number of related substances have been studied in experimental and human disease ${ }^{4}$. Several reports using TIPS to treat HPS were done and others are in progress, but no effective benefit has been presented ${ }^{11}$. Supplement oxygen is effective to improve dyspnea.

Finally, liver transplantation is the only effective treatment for patients with HPS and complete resolution of gas exchange abnormalities is reported in $>80 \%$ on them ${ }^{7,8}$. However, an early prospective study found that those with severe HPS $\left(\mathrm{PaO}_{2}\right.$ of $<50 \mathrm{mmHg}$ ) had a marked increase in postoperative mortality ${ }^{4,10}$. 


\section{CONCLUSION}

Was observed a high rate of hypoxemia in patients on waiting list liver transplant. Due to the high severity and morbidity, is suggested a better monitoring and therapeutic support to hypoxemic patients on liver transplant waiting list.

\section{REFERENCES}

1. Fallon MB: Mechanisms of pulmonary vascular complications of liver disease: hepatopulmonary syndrome. J Clin Gastroenterol 2005, 39(4 Suppl 2):S138-142.

2. Fallon MB, Krowka MJ, Brown RS, Trotter JF, Zacks S, Roberts KE, Shah VH, Kaplowitz N, Forman L, Wille K et al: Impact of hepatopulmonary syndrome on quality of life and survival in liver transplant candidates. Gastroenterology 2008, 135(4):11681175.

3. Fallon $M B$, Zhang J: The lung in liver disease: old problem, new concepts. Trans Am Clin Climatol Assoc 2013, 124:250-262.
4. Krowka MJ, Fallon MB: Liver transplantation for hepatopulmonary syndrome (HPS): what is the MESSAGE? Am J Transplant 2008, 8(5):911-912.

5. Luo B, Tang L, Wang Z, Zhang J, Ling Y, Feng W, Sun JZ, Stockard CR, Frost AR, Chen YF et al: Cholangiocyte endothelin 1 and transforming growth factor beta1 production in rat experimental hepatopulmonary syndrome. Gastroenterology 2005, 129(2):682-695.

6. Machicao VI, Fallon MB: Hepatopulmonary syndrome. Semin Respir Crit Care Med 2012, 33(1):11-16.

7. Palma DT, Fallon MB: The hepatopulmonary syndrome. J Hepatol 2006, 45(4):617-625.

8. Paramesh AS, Husain SZ, Shneider B, Guller J, Tokat I, Gondolesi GE, Moyer S, Emre S: Improvement of hepatopulmonary syndrome after transjugular intrahepatic portasystemic shunting: case report and review of literature. Pediatr Transplant 2003, 7(2):157-162.

9. Rodríguez-Roisin R, Krowka MJ: Hepatopulmonary syndrome-a liver-induced lung vascular disorder. N Engl J Med 2008, 358(22):2378-2387.

10.Zhang J, Fallon MB: Hepatopulmonary syndrome: update on pathogenesis and clinical features. Nat Rev Gastroenterol Hepatol 2012, 9(9):539-549.

11. Rodríguez-Roisin R, Krowka MJ, Hervé P, Fallon MB, Committee ETFP-HVDPS: Pulmonary-Hepatic vascular Disorders (PHD). Eur Respir J 2004, 24(5):861-880. 